\title{
The Effectiveness of Attack with Epee Weapon in Fencing Competition in Kendal Regency Year 2020
}

\author{
Rubianto Hadi ${ }^{1}$, Kriswantoro ${ }^{2}$, Moch. Senoadji Karjadi ${ }^{3}$ \\ \{rubianto.hd@mail.unnes.ac.id ${ }^{1}$, krisfaras2@mail.unnes.ac.id ${ }^{2}$, karjaditirta@mail.unnes.ac.id ${ }^{3}$ \} \\ Universitas Negeri Semarang, Semarang, Indonesia ${ }^{1,2,3}$
}

\begin{abstract}
This study aims to determine the percentage of the effectiveness of attack techniques using epee weapon used by athletes in fencing competition at the regional level in Kendal in year 2020. The research sample were 4 junior female athletes who succeeded in the semifinals and finals. The results showed that attack technique effectiveness include 1) the counter-attack technique was $85.71 \%, 2$ ) the wrist attack technique was $75 \%, 3$ ) the circular flash technique was $71.42 \%, 4)$ the one-step attack technique was $66.67 \%, 5)$ the direct attack technique was $62.50 \%, 6$ ) the beat attack technique was $60 \%, 7)$ the waist remise six circle technique was $56.25 \%$, 8) flash technique was $54.54 \%$, 9) waist remise six flash technique was $33.33 \%$, 10) compound technique was $31.25 \%, 11$ ) technique down to eignt leg pricks, was $30 \%, 12$ ) leg prick technique moved to six, was $25 \%, 13$ ) doule-flash attack technique was $20 \%, 14$ ) twostrike technique was $0 \%$.
\end{abstract}

Keywords: Efectiveness, Attacking Technique, Fencing, Epee Weapon.

\section{Introduction}

Fencing is a martial arts that uses weapon and develops into a cultural art that emphasizes skill techniques such as cutting, stabbing, or deflecting enemy weapons by optimizing hand dexterity (Atri Widowati \& Graffite Decheline, 2018).

Although there are many techniques in fencing, not all of them are applied by athletes when competing with opponents. The fact that what happens in the arena is that a fencer sometimes does a stab that is not right at a legitimate target so that the attack does not produce points, this situation is used as an advantage by the opponent to get points. The attack is easily deflected by the opponent. Some fencing athletes tend to only perform one attack technique without wanting to vary the attack technique even though the technique does not generate points in a match.

The fencing attack movement is built starting with a full forward position, the forward legs are balanced with the buttocks which must be stable together with the arms, the hands are fully extended and pointing towards the opponent with power and hind leg repulsion. (Faidillah Kurniawan 2010:57).

According to Alie Humaedi (2016: 41) effectiveness is the level of achieving a certain goal, both in terms of results and efforts as measured by quality, quantity, and timeliness according to certain procedures and measures. Therefore, by using statistical analysis of technical effectiveness the coach can find out what techniques are effective for generating points, so that the coach can guide his athletes to use the right techniques when competing. 
The trainer can understand the function and benefits of evaluation by using statistical data. The trainer is no longer just evaluating by simply making observations without any statistical data. This data is also useful to support the training program that will be created later. Therefore, researchers want to carry out research at regional level fencing competitions in Kendal Regency in 2020 to determine the effectiveness of attack techniques using epee weapon when athletes use them in competing.

Epee is one of three types of fencing weapons that differ in match equipment, weapon shape, and target area suitability. The epee weapon is the same length as the floret, but heavier, with a larger protector (to protect the hand from the touch of a legitimate opponent's weapon) and a more rigid blade.

The attack movement is initiated by a straightening motion of the arm that holds the sword, which reaches out with the tip of the sword to aim and stab the opponent into the target area. Fencing requires puncture accuracy as explained by Mochamad Sajoto (1988: 59) that, "accuracy is one's ability to control free movements towards a target, this means can be a distance or perhaps a direct object that must be targetted".

Direct attack techniques, in this type of EPE weapon, players can immediately attack because there are no provisions for attack rights such as for the types of floret and saber weapons. So whoever is fast with the tip of the weapon piercing the legal surface then the athlete gets the points (Dede Syamsul Ma'Arif, 2015:3).

A one-step strike technique, this movement begins with positioning the "stance" which is commonly known as the ready position in the fencing, the feet are approximately fifteen inches between the front and rear legs at a 90 degree leg angle. The position of the heel of the front and back foot is on the same line. The front leg is straight pointing towards the enemy / opponent, while the back leg is rotating at an angle of 90 degrees. (Faidillah Kurniawan, 2010:52).

Redoublement attacks, this movement is commonly where the player performs the attack twice in one movement quickly without pausing footsteps or bending the hands. As explained by Rogers (2013:64) "A redoublement from the lunge, or by lunging or flèche after returning to guard".

flash is a movement the fencer makes by running or jumping from an en garde position and landing on the hind legs (Rakita dan Shteynbakh, 2013:106).

The attack circle technique is a movement that is carried out under the opponent's command which is usually called a coumpound, with the direction of the tip of the weapon coming out or in (Faidillah Kurniawan, 2010:59). Compound is evasion by avoiding the opponent's weapon, from the side the weapon is linked to and then raising it to the opposite side.

The counter-attack technique can be described as a defensive move by fencing that successfully deflects a sword / weapon strike from the target area, preventing a legitimate touch (Faidillah Kurniawan, 2010:59).

The wrist strike technique is performed when their opponent steps forward but slightly open the upper, right, left, and lower wrists with a close distance the weapon is moved lengthwise with the stab direction of the open wrist and close to the tip of the weapon. (Rogers, 2013:154).

Beat attack is a beat that is done by opening the three fingers that hold the weapon and closing it again by flexing the wrist, to give a sharp blow to the blade of the opponent's weapon. (Rogers, 2013:40).

Based on an interview with Gerardus Felix Bolang as the coach of BPLOP Central Java on July 23, 2020, the were some information as follows, 
1) circle six waist remise is the development of a modern fencing technique with the main movement of this technique where the weapon from a position inside the target area moves to the outer area of the target area by moving the tip of the weapon from the inside out through the bottom of the opponent's weapon to form a circle (circle).

2) technique down to eignt leg pricks is carried out by lowering the tip of the weapon from the position of the seven to eight stab or from the four to the eight with the direction of the stab of the opponent's leg. In the process of displacement, the tip of the weapon is attempted to form a semicircle so that it is difficult for the opponent to avoid the fencer with the aim of puncturing not the thighs but the legs of the knees to the opponent's shoes.

3) leg prick technique moved to six is one of the attack techniques where a stab towards the leg is only a trick for the opponent. Scams are designed to attract defensive action towards the point of being attacked. Usually used as a distraction to force your opponent to focus more energy and focus on a certain area. To weaken the strength of the opponent in another area, the point of the weapon is fixed towards the opponent's feet, then when the opponent responds to block the athlete's weapon, the direction of the weapon is focused on a sixth circular motion in which the position of the weapon is moved to the area outside the target area by moving the tip of the weapon from below to move up past the bottom opponent's weapon so that it forms a circle. Then the tip of the weapon is pointed upwards to attack with the target chest to stomach.

4) The flash movement with a circle is carried out when performing a flash or jumping technique where the athlete's weapon is straightened to lure the opponent to parry. If the opponent is hooked by the trick, the athlete moves the tip of the weapon to the outside area as well as in the opponent's target plane (forming a small circle with the tip of the weapon from the inside out or from the outside in).

5) The waist remise six flash also includes a one-two technique where the flash with the weapon is moved towards block six is used as the main movement in this technique, if the movement fails or is blocked by the opponent, the athlete remakes by moving the tip of the weapon to the target area of the opponent.

The attack technique movement twice and then flash is a variation of the redoublement technique which is performed when the athlete uses the attack technique twice in a match but does not reach the target area so the athlete adds the flash movement to this technique.

\section{Method}

Type of Research. This study used a survey method, with a percentage descriptive form. Sugiyono (2013) states that the survey method is used to obtain data from certain natural (not artificial) places. In collecting data, researchers circulate questionnaires, tests, structured interviews and so on (treatment is not like in experiments). Suharsimi Arikunto (2013) states that descriptive research is research that is intended to investigate the circumstances, conditions, or other things that have been mentioned, the results of which are presented in the form of a research report.

Time and Place of Research. The research data was collected at Kebondalem Stadium, Kendal Regency, Central Java. Then this research was carried out on February 15 and 16, 2020. 
Population and Sample. In conducting this research, researchers used all fencing athletes, both junior and senior female athletes who took part in the Fencing Championship in Kendal Regency in 2020, totaling 30 athletes. Then the researchers determined the sample by selecting junior female fencing athletes who made it into the semi-finals to the finals, totaling 4 athletes.

Technique in Collecting the Data. In this study, the researcher was assisted by two colleagues who were in charge of recording and taking notes all activities and results in the competition, both in the form of points and the techniques used by athletes in carrying out attacks. Then the researcher conducted an analysis of the results of the observations and records made during the fencing competition.

Technique in Analyzing Data. Analysis of the data used in this study using percentage descriptive statistics. According to Sugiyono (2009), descriptive statistics are statistics that are used to analyze data by describing or describing the collected data as it is without making generalized conclusions or generalizations. The formulas used in this study are:

$$
\mathrm{DP}=\frac{n}{N} \times 100 \%
$$

Criteria :

$\begin{array}{ll}\mathrm{Dp} & : \text { Descriptive Percentage } \\ \mathrm{n} & : \text { Number of attacks earned points } \\ \mathrm{N} & : \text { The total number of attacks } \\ 100 \% & : \text { The percentage rate level }\end{array}$

\section{Result and Discussion}

Based on the observation carried out on each junior female fencing athlete competition data from the semifinals to the finals related to the epee weapon attack technique, there are 14 indicators such as direct attack technique, one-step attack technique, two-strike technique, flash technique, coumpound technique, counter-attack technique, wrist attack technique, beat attack technique, waist six remise circle technique, downward eight leg stab technique, six move leg stab technique, circular flash technique, waist remise six flash technique, and redoublement then flash technique. The descriptive analysis of the research data is as follows:

Table 1. Children demography status

\begin{tabular}{lccccc}
\hline Nb. & $\begin{array}{c}\text { Attack } \\
\text { Techniques }\end{array}$ & $\begin{array}{c}\text { Number of } \\
\text { attacks earned } \\
\text { points (n) }\end{array}$ & $\begin{array}{c}\text { The total } \\
\text { number of } \\
\text { attacks (N) }\end{array}$ & $\mathrm{DP}=\frac{n}{\mathrm{~N}} \times 100 \% \begin{array}{c}\text { Result } \\
(\%)\end{array}$ \\
\hline 1. & Direct Attack & 10 & 16 & $\mathrm{DP}=\frac{10}{16} \times 100 \%$ & $62,50 \%$ \\
\hline 2. & $\begin{array}{c}\text { one-step attack } \\
\text { technique }\end{array}$ & 12 & 18 & $\mathrm{DP}=\frac{12}{18} \times 100 \%$ & $66,67 \%$ \\
\hline 3. & two-strike & 0 & 9 & $\mathrm{DP}=\frac{0}{9} \times 100 \%$ & $0 \%$ \\
\hline
\end{tabular}




\begin{tabular}{|c|c|c|c|c|c|}
\hline 4. & Flash & 6 & 11 & $\mathrm{DP}=\frac{6}{11} \times 100 \%$ & $54,54 \%$ \\
\hline 5. & coumpound & 5 & 16 & $\mathrm{DP}=\frac{5}{16} \times 100 \%$ & $31,25 \%$ \\
\hline 6. & $\begin{array}{c}\text { counter-attack } \\
\text { technique }\end{array}$ & 18 & 21 & $\mathrm{DP}=\frac{18}{21} \times 100 \%$ & $85,71 \%$ \\
\hline 7. & $\begin{array}{c}\text { wrist attack } \\
\text { technique }\end{array}$ & 3 & 4 & $\mathrm{DP}=\frac{3}{4} \mathrm{X} 100 \%$ & $75 \%$ \\
\hline 8. & Beat Technique & 6 & 10 & $\mathrm{DP}=\frac{6}{10} \times 100 \%$ & $60 \%$ \\
\hline 9. & $\begin{array}{c}\text { waist remise six } \\
\text { circle }\end{array}$ & 9 & 16 & $\mathrm{DP}=\frac{9}{16} \times 100 \%$ & $56,25 \%$ \\
\hline 10. & $\begin{array}{l}\text { Turun ke delapan } \\
\text { tusuk kaki }\end{array}$ & 3 & 10 & $\mathrm{DP}=\frac{3}{10} \times 100 \%$ & $30 \%$ \\
\hline 11. & Leg Stab & 1 & 4 & $\mathrm{DP}=\frac{1}{4} \times 100 \%$ & $25 \%$ \\
\hline 12. & $\begin{array}{l}\text { circular flash } \\
\text { technique }\end{array}$ & 5 & 7 & $\mathrm{DP}=\frac{5}{7} \times 100 \%$ & $71,42 \%$ \\
\hline 13. & $\begin{array}{l}\text { waist remise six } \\
\text { flash technique }\end{array}$ & 1 & 3 & $\mathrm{DP}=\frac{1}{3} \mathrm{X} 100 \%$ & $33,33 \%$ \\
\hline 14. & $\begin{array}{l}\text { redoublement }+ \\
\text { flash technique }\end{array}$ & 1 & 5 & $\mathrm{DP}=\frac{1}{5} \times 100 \%$ & $20 \%$ \\
\hline
\end{tabular}

Based on the calculation of the table above, the results showed that direct attack has a percentage value by $62.50 \%$, one-step attack has a percentage value by $66.67 \%$, two-strike has a percentage value by $0 \%$, flash has a value a percentage by $54.54 \%$, coumpound attack has a percentage value by $31.25 \%$, counter-attack has a percentage value by $85.71 \%$, wrist attack technique has a percentage value by $75 \%$, beat attack has a percentage value by $60 \%$, waist six remise circle has a percentage value by $56.25 \%$, Turun ke delapan tusuk kaki has a percentage value by $30 \%$, Leg Stab has a percentage value of $25 \%$, circular flash technique has a percentage value by $71.42 \%$, waist remise six flash technique has a percentage value by $33.33 \%$, and redoublement + flash technique has a percentage value by $20 \%$.

As for more details, it can be seen in the following diagram to explain the percentage level of attack techniques using epee weapon on female junior athletes from the most effective to 


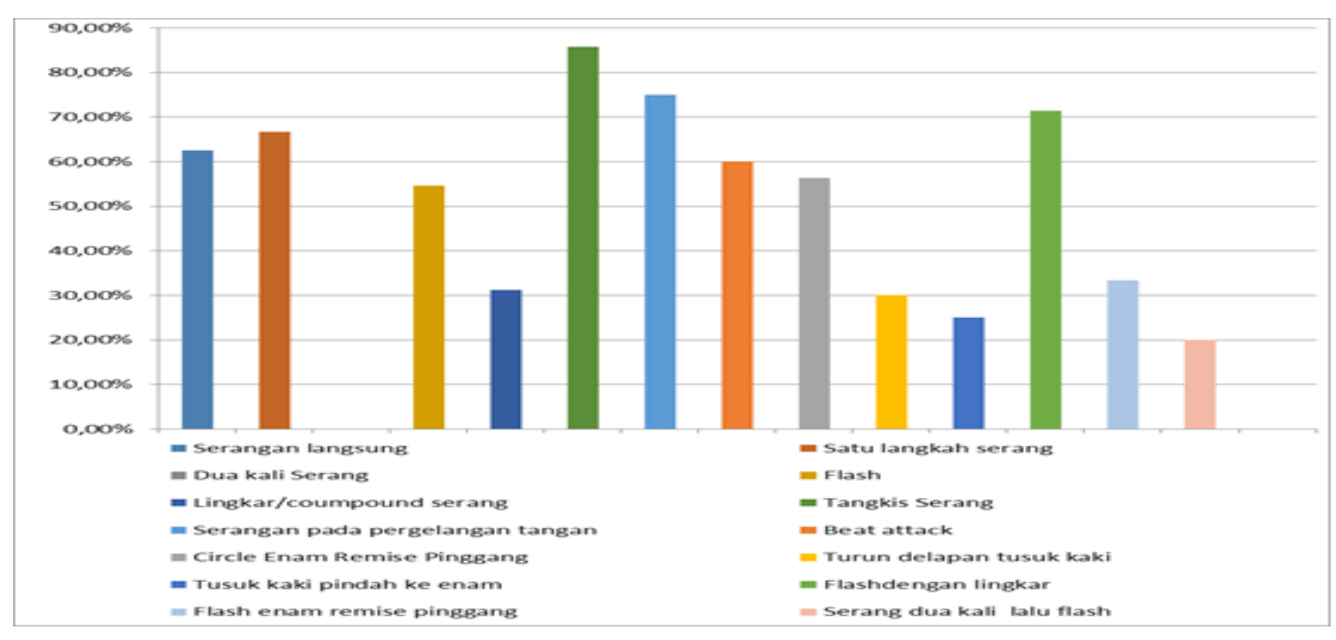

Fig. 3.1 Percentage of Attack Techniques Used by The Athletes

From the results of these studies, the results of the effectiveness of attacks with epee weapon were obtained from the highest to the lowest as follows:

1) The counter-attack technique with the total number of points that entered 18 points from the 21 techniques of attack that was carried out so that it had the largest percentage compared to the other 13 techniques, namely $85.71 \%$. Many athletes use defensive techniques when they are in an advantageous position when the opponent is weak, such as when the opponent makes an attack but is constrained by distance so that it does not reach the target.

2) The attack technique on the wrist gets 3 points from the 4 attack techniques on the wrist that are carried out, so that the percentage of the effectiveness of the technique is $75 \%$. This technique has a large percentage even though only 3 points were successfully performed because of the 4 techniques performed only 1 technique failed compared to doing many techniques but did not get points, then the wrist attack technique was said to be effective.

3) The flash technique with a circumference with the number of points entering as many as 5 points from the 7 flash techniques with the circumference performed, so that it has an effectiveness percentage of $71.42 \%$. This technique is said to be effective because it has a large percentage even though the flash technique with a circumference is only used by 2 athletes in this match.

4) The one-step attack technique succeeded in obtaining 12 points from 18 trials so that it had an effectiveness percentage by $66.67 \%$. The one-step attack technique is effective to use and easy to apply, although sometimes the distance from the opponent is often an obstacle.

5) Direct attack technique managed to get 10 points from 16 attempts. The direct attack technique has an effectiveness percentage of $62.50 \%$. Direct attack techniques are quite effective when athletes take advantage of passive and hesitant opponents in attacking, or in other words, giving the opponent too freedom to attack the target area.

The next attack techniques that have a moderate level of effectiveness are as follows: 
1) Beat attack technique managed to get 6 points from 10 attempts so that it has an effectiveness percentage of $60 \%$. Beat attack technique is quite effective to use when outwitting your opponent by hitting the opponent's weapon.

2) The circle six waist remise technique obtained 9 points from 16 attempts so it has an effectiveness percentage by $56.25 \%$. The circle six waist remise technique is quite effective because many athletes use this technique.

3) The flash technique was able to get as many as 6 points from 11 attempts carried out so that it had an effectiveness percentage by $54.54 \%$. The flash technique is less effective in use by athletes because the points achieved are less than the number of techniques used. Athletes find it difficult to use the flash technique because the movement is not easy to demonstrate, especially if the athlete has short leg posture or less than optimal leg repulsion when doing the flash.

Attack techniques with a low level of effectiveness are as follows:

1) The waist remise six flash technique succeeded in obtaining 1 point from 3 attempts so that it had an effectiveness percentage by $33.33 \%$. The waist remise six flash technique is less effective to use because it is rarely performed by athletes so that the points obtained are classified as low.

2) The technique of turun ke delapan tusuk kaki succeeded in obtaining 3 points from 10 attempts so that it had an effectiveness percentage by $30 \%$.

3) The tusuk kaki pindah ke enam technique gets 1 point out of 4 attempts so it has a percentage by $25 \%$. This technique is rarely used by athletes because athletes tend to be hesitant and not maximal in doing it. They also failed to get points due to the movements that were difficult to make and easy for the opponent to intercept.

4) The redoublement + flash technique managed to get 1 point out of 5 attempts so that it had an effectiveness percentage by $20 \%$. The double strike technique is ineffective because many athletes use it infrequently and do not earn points proportional to the number of attempts performed. Athletes fail to get points due to inappropriate movement.

5) The fifth attack technique that has a low level of effectiveness is a two-strike technique that does not get any points from 9 attempts so that it has a technique effectiveness percentage of $0 \%$. The two-strike technique is used by many athletes but fails to get points because the athlete has difficulty in determining the distance from the opponent.

\section{Conclusion}

Conclusion. Based on the results of research and discussion in the previous chapter, it can be concluded that there were fourteen attack techniques used by athletes in the Fencing competition in Kendal Regency year 2020. The most effective attack technique was counterattack technique which has a percentage value by $85.71 \%$. The second was the wrist attack technique on which has a percentage value by $75 \%$. The third was the circular flash technique which has a percentage value by $71.42 \%$. The fourth was the one-step attack technique which has a percentage value by $66.67 \%$. The fifth was the direct attack technique which has a percentage value by $62.50 \%$. The sixth was the beat attack technique which has a percentage value by $60 \%$. The fifth was the waist remise six circle technique which has a percentage value by $56.25 \%$. The eighth rank was the flash technique which has percentage value by $54.54 \%$. The ninth was the waist remise six flash technique which has a percentage value of 
$33.33 \%$. The tenth rank was the coumpound attack technique which has a percentage value by $31.25 \%$. The eleventh was the turun ke delapan tusuk kaki which has a percentage value by $30 \%$. The twelfth was teknik tusuk kaki pindah ke enam which has a percentage value by $25 \%$. The thirteenth was the redoublement + flash which has a percentage value by $20 \%$, and the fourteenth or the last was two-strike technique which has a percentage value by $0 \%$.

Recommendation. Based on the results that have been obtained from this research, there are several suggestions that can be conveyed:

1) The coaches are expected to guide athletes to maintain techniques that are already effective in gaining points.

2) The coaches are able to improve or develop less effective techniques when exercising and can apply the results of this study as a reference in developing an exercise program.

3) Athletes are expected to be confident in using the techniques that have been practiced in training season so that they can get optimal points during competition.

\section{References}

[1] Alie Humaedi. 2016. Etnografi Bencana. Yogyakarta: PT Lkis Printing Cemerlang.

[2] Atri Widowati dan D. Graffite. 2018. Latihan Shadow Fencing Anggar Untuk Atlet Anggar Provinsi Jambi. Cerdas Sifa. Edisi: 1. No.1. Jambi. UNJA.

[3] Dede Syamsul Ma'Arif. 2015. "Kontribusi Power Lengan Dan Power Tungkai Terhadap Hasil Serangan Langsung Dalam Cabang Olahraga Anggar Jenis Senjata Degen”. UPI. Bandung.

[4] Faidillah Kurniawan. 2010. Buku Mengenal Olahraga Anggar. [online], http://staff.uny.ac.id/sites/default/files/132313281/BUKU\%20MENGENAL\%20OLAHRAGA\%20 ANGGAR.pdf. Diakses Pada Tanggal 20 Desember 2019.

[5] Rakita, M., and V. Shteybakh. 2013. Fencing Encyclopaedia. Moscow: Yonebek.

[6] Rogres, Ed. 2013. Advanced Fencing Techniques Discussions with Bert Bracewell.[Online], https://books.google.co.id/books?hl=id\&lr=\&id=lpR8AwAAQBAJ\&oi=fnd\&pg=PP10\&dq=fencin $\mathrm{g}+$ techniques\&ots=K1plkZuXsD\&sig=29LWrCsELMvyfHKHrUPpZxng3sw\&redir_esc $=\mathrm{y} \# \mathrm{v}=\mathrm{one}$ page\&q=fencing\%20techniques\&f=true. Diakses pada tanggal 28 Desember 2019.

[7] Sugiyono. 2009. Metode Penelitian Kuantitatif, Kualitatif, dan $R \& D$. Bandung: Alfabeta.

[8] ----. 2013. Metode Penelitian Kuantitatif kualitatif, dan R\&D. Bandung: Alfabeta.

[9] Suharsimi Arikunto. 2013. Prosedur Penelitian Suatu Pendekatan Praktik. Jakarta: Rineka Cipta. 